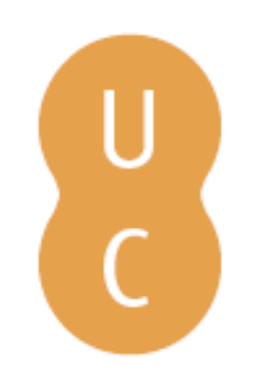

\title{
nombalina
}

\section{"Pensar a Europa. Uma Perspectiva Cultural e Política": uma visão desde a Ciência Jurídica}

\author{
Autor(es): $\quad$ Lopes, Dulce
}

Publicado por: Imprensa da Universidade de Coimbra

URL

persistente: URI:http://hdl.handle.net/10316.2/47301

DOI: $\quad$ DOI:https://doi.org/10.14195/978-989-26-1849-4_10

Accessed : $\quad$ 26-Apr-2023 10:50:23

A navegação consulta e descarregamento dos títulos inseridos nas Bibliotecas Digitais UC Digitalis, UC Pombalina e UC Impactum, pressupõem a aceitação plena e sem reservas dos Termos e Condições de Uso destas Bibliotecas Digitais, disponíveis em https://digitalis.uc.pt/pt-pt/termos.

Conforme exposto nos referidos Termos e Condições de Uso, o descarregamento de títulos de acesso restrito requer uma licença válida de autorização devendo o utilizador aceder ao(s) documento(s) a partir de um endereço de IP da instituição detentora da supramencionada licença.

Ao utilizador é apenas permitido o descarregamento para uso pessoal, pelo que o emprego do(s) título(s) descarregado(s) para outro fim, designadamente comercial, carece de autorização do respetivo autor ou editor da obra.

Na medida em que todas as obras da UC Digitalis se encontram protegidas pelo Código do Direito de Autor e Direitos Conexos e demais legislação aplicável, toda a cópia, parcial ou total, deste documento, nos casos em que é legalmente admitida, deverá conter ou fazer-se acompanhar por este aviso.

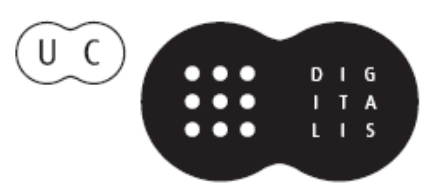


Euro-Atlântico:

Espaço de Diálogos

Isabel Maria Freitas Valente

Iranilson Buriti de Oliveira

(Coord)

\section{VISÕES \\ INTERDISCIPLINARES \\ DA EUROPA \\ E DO MUNDO:}

uma experiência de convergência

disciplinar em homenagem a

Maria Manuela Tavares Ribeiro

Alexandra Aragão

Isabel Maria Freitas Valente

Dulce Lopes

(org.)

Editora da Universidade Federal de Campina Grande

Imprensa da Universidade de Coimbra

2019 


\section{"PENSAR A EUROPA. UMA PERSPECTIVA CULTURAL E POLÍTICA", UMA VISÃO DESDE A CIÊNCIA JURÍDICA}

Dulce Lopes

O tema eleito por Isabel Baltazar e o poema que o ilustra, de Adolfo Casais Monteiro, não poderiam ter sido melhor casados com o pensamento da Homenageada, a Senhora Doutora Maria Manuela Tavares Ribeiro.

O acentuar da importância da Europa da Cultura, assente numa herança comum em permanente construção, e da memória histórica não só dos muitos progressos europeus, mas também dos vários momentos em que a episódios de imperialismos, nacionalismos e intolerâncias se seguiram momentos destrutivos daquele ideário e património valorativo comum, é particularmente evidente nos escritos das Autoras e especialmente relevante nos nossos dias.

O "futuro sólido" que se sonhou para a Europa corre o risco de se ver convertido num "presente instável", instabilidade que pode deixar de ser puramente conjuntural - qualquer projeto é iminentemente iterativo e reflexivo - para se instalar de forma mais estrutural minando os fundamentos e propósitos da União Europeia.

De facto, a perspetiva histórica e cultural marca o "início" da União Europeia como uma construção comum de interesses dos povos europeus e não de arranjos puramente económicos, estes estando contidos num projeto mais alargado, de, como se sabe, criação de uma "solidariedade de facto" para se caminhar no sentido da consolidação de uma cada vez mais próxima comunidade jurídico-política.

Segundo Isabel Baltazar "O começo da Europa tinha esta perspectiva política, mas, também, moral: os europeus tinham perdido, pouco a pouco, a capacidade de viver juntos e de associar as suas forças criadoras". Acrescentando se não serão estas "palavras proféticas para os tempos que vivemos?".

É altura por isso para a Autora de (re)construir o futuro da Europa, 
"a partir da História e da Cultura, reconhecendo uma identidade física, histórica e cultural na União Europeia e caminhando do ideal para o real, do sonho para a realidade, através desta Identidade Europeia feita da História, Cultura e Geografia (...)".

Concordando plenamente com a nossa interlocutora e na linha do pragmatismo político que a própria advoga, não podemos deixar de assinalar que a construção europeia é feita de avanços mas também de alguns, desejavelmente pontuais e ultrapassáveis, recuos.

O caminho não é sempre feito linearmente, do ideal para o real, já que este conforma tantas vezes todos os estratos da vida política, jurídica, sociológica, económica, etc. É, todavia, preciso reconhecer estes condicionalismos e não pactuar com aquilo que efetivamente constitui o "inegociável" europeu, a matriz histórica-cultural da Europa, dos seus Estados, povos e cidadãos, por muito que alguns destes se sintam tentados a comprometer aquela matriz em prol de ganhos imediatos ou de ideologias mal guiadas (ou mal compreendidas) e destrutivas.

É esse inegociável que tem de ser preservado a todo o custo, mantendo-se a União Europeia um espaço de liberdade, mesmo e sobretudo face à diferença, mas elevando ao estatuto de intocáveis os fundamentos axiológicos que a baseiam.

Admitimos, por isso, que muito do que se percebe hoje como "adquirido" comunitário não tenha necessariamente de o ser e que uma eventual revisão de políticas e medidas comunitárias possa servir para ajustar a União Europeia às necessidades e aspirações tanto dos Estados como dos cidadãos da União, designadamente devolvendo-lhes alguma capacidade que foram perdendo para gerir os seus próprios interesses e tomar as suas autónomas decisões.

Há contudo, limites materiais àquela revisão, já que hoje, estruturalmente, a União Europeia não pode deixar de ser um projeto de paz, tributária simultaneamente de uma lógica de equilíbrio de legitimação entre Estados e cidadãos, e assente na ideia e na tutela da dignidade da pessoa humana, qualquer que ela seja.

Vemos, por isso, no actual processo do Brexit um momento conjuntural e reflexivo da União, do qual ela necessariamente sairá diferente, mas 
eventualmente fortalecida nessa diferença. Já nos preocupam mais os processos que têm vindo a correr relativamente à Polónia e à Hungria, uma vez que estes não correspondem ao exercício de uma autonomia de saída ou retirada da União (mas preservando, pelo menos por ora, o mesmo húmus essencial desta), mas à tentativa de, por dentro da União, minar os seus fundamentos, corroendo ou esboroando as dimensões "intocáveis" a que nos referimos, desde logo a independência do poder judicial e a garantia da liberdade de expressão. Sintomas estes sim de um inaceitável "regresso ao passado"... 